\title{
The influence of calcium sulfate content on the hydration of belite-calcium sulfoaluminate cements with different clinker phase compositions
}

\author{
Maruša Mrak (D) Frank Winnefeld • Barbara Lothenbach • Sabina Dolenec
}

Received: 4 September 2021 / Accepted: 22 October 2021/Published online: 5 November 2021

(C) The Author(s) 2021

\begin{abstract}
The influence of different amounts of gypsum on the hydration of a belite-rich and a ye'elimite-rich belite-calcium sulfoaluminate clinker (BCSA) was investigated. The hydration kinetics, phase assemblages and compressive strength development of cements prepared using ye'elimite/ calcium sulfate molar ratios of $1,1.5$ and 2 were studied. Besides ettringite and monosulfate, aluminium hydroxide, strätlingite, $\mathrm{C}-\mathrm{S}-\mathrm{H}$, iron-containing siliceous hydrogarnet and hydrotalcite were present as hydration products. Increasing the amount of gypsum
\end{abstract}

Supplementary Information The online version contains supplementary material available at https://doi.org/10.1617/ s11527-021-01811-w.

M. Mrak · S. Dolenec $(\bowtie)$

Slovenian National Building and Civil Engineering Institute, Dimičeva ulica 12, 1000 Ljubljana, Slovenia e-mail: sabina.dolenec@zag.si

M. Mrak

Jožef Stefan International Postgraduate School, Jamova cesta 39, 1000 Ljubljana, Slovenia

F. Winnefeld · B. Lothenbach

Empa, Swiss Laboratories for Materials Science and Technology, Überlandstrasse 129, 8600 Dübendorf, Switzerland

\section{B. Lothenbach}

Department of Structural Engineering, Norwegian University of Science and Technology (NTNU), Trondheim, Norway increased the ratio of ettringite to monosulfate formed in the cement paste, lowered the amount of pore solution, delayed the dissolution of belite and ferrite, decreased the formation of strätlingite and, in the case of the ye'elimite-rich BCSA, led to an increase in compressive strength. Increased amounts of belite in the clinker led to the formation of higher quantities of $\mathrm{C}-\mathrm{S}-\mathrm{H}$, at the expense of strätlingite and a lower compressive strength, as belite has a lower degree of reaction than ye'elimite and due to the formation of more $\mathrm{C}-\mathrm{S}-\mathrm{H}$ and strätlingite compared to the more space-filling ettringite. The thermodynamic model established for BCSA cement hydration agrees well with the experimental data. Compressive strength directly correlated with bound water from thermogravimetric analyses and inversely correlated with the porosity calculated from thermodynamic modelling.

Keywords Belite-calcium sulfoaluminate cement . Gypsum · Hydration · Thermodynamic modelling

\section{Introduction}

Cement manufacturing is one of the most important industries. After water, the most used material in the world is concrete, which is mainly based on Portland cement, aggregates and water. During the production of Portland cement high emissions of $\mathrm{CO}_{2}$ are released 
into the atmosphere, and a high amount of energy is consumed $[1,2]$. To reduce the environmental impact related to cement production, alternative binders, such as belite-calcium sulfoaluminate (BCSA) cements, have been developed. BCSA cements are considered low $\mathrm{CO}_{2}$ and eco-friendly building materials, not only reducing emissions by up to $30 \%$ compared to Portland cement, but also lowering energy consumption [3-5]. Furthermore, substantial amounts of industrial wastes can be used to prepare BCSA cements, allowing natural raw materials to be preserved. As indicated by their name, belite-calcium sulfoaluminate cement clinkers contain belite $\left(\mathrm{Ca}_{2}\right.$ $\mathrm{SiO}_{4}$ or $\left.\mathrm{C}_{2} \mathrm{~S}\right)$ and calcium sulfoaluminate $\left(\mathrm{Ca}_{4}\left(\mathrm{AlO}_{2}\right)_{6}\right.$ $\mathrm{SO}_{3}$ or $\left.\mathrm{C}_{4} \mathrm{~A}_{3} \overline{\mathrm{S}}\right)$ as the main phases, together with ferrite $\left(\mathrm{Ca}_{2}(\mathrm{Al}, \mathrm{Fe})_{2} \mathrm{O}_{5}\right.$ or $\left.\mathrm{C}_{4} \mathrm{AF}\right)$ and other minor phases $[6,7]$.

Belite-calcium sulfoaluminate cements are prepared by blending the clinker with a calcium sulfate source in the form of gypsum $\left(\mathrm{CS}_{\bar{S}} \mathrm{H}_{2}\right)$, anhydrite $\left(\mathrm{CaSO}_{4}\right.$ or $\left.\mathrm{C} \overline{\mathrm{S}}\right)$ and/ or bassanite $\left(\mathrm{C}_{\overline{\mathrm{S}}} \mathrm{H}_{0.5}\right)$ [8-12]. Calcium sulfate works as a set regulator, an its addition is used to achieve optimum compressive strength and dimensional stability [12-16]. Furthermore, the type and amount of calcium sulfate can also modify the hydration processes and the water required to achieve full hydration $[6,10,11,15,17,18]$.

During early hydration, ye'elimite rapidly reacts with calcium sulfate and water, which leads to the formation of ettringite $\left(\mathrm{C}_{6} \mathrm{AS}_{3} \mathrm{H}_{32}\right)$ as the main crystalline hydration product and amorphous or poorly crystalline aluminium hydroxide $\left(\mathrm{AH}_{3}\right)$ [3, 6, 8, 10, 19, 20], according to Eq. 1:

$$
\begin{aligned}
& \mathrm{C}_{4} \mathrm{~A}_{3} \overline{\mathrm{S}}+2 \mathrm{C}_{\overline{\mathrm{S}}} \mathrm{H}_{\mathrm{x}}+(38-2 x) \mathrm{H} \\
& \quad \rightarrow \mathrm{C}_{6} \mathrm{~A}_{3} \mathrm{H}_{32}+2 \mathrm{AH}_{3}(x=0,0.5,2)
\end{aligned}
$$

Ettringite precipitates when the molar ratio of calcium sulfate to ye'elimite ( $M$-value) is below 2 $(M<2)$, until the added calcium sulfate is depleted $[11,15,21,22]$. If the molar ratio of calcium sulfate to ye'elimite (the so-called " $M$-value") is more than 2 $(M>2)$ a surplus of calcium sulfate is still present after hydration has been completed $[15,16]$. An $M$ value below 1.5 is typical for CSA cements with rapid setting and hardening properties, while values between 1.5 and 2.5 are used for expansive cements [16, 23, 24].
Once the calcium sulfate source has been consumed and sufficient water is still available, monosulfate $\left(\mathrm{C}_{4} \mathrm{~A} \overline{\mathrm{S}} \mathrm{H}_{12}\right)$ precipitates, again together with aluminium hydroxide $[6,11,15,21,25,26]$, according to Eq. 2:

$\mathrm{C}_{4} \mathrm{~A}_{3} \overline{\mathrm{S}}+18 \mathrm{H} \rightarrow \mathrm{C}_{4} \mathrm{~A} \overline{\mathrm{S}} \mathrm{H}_{12}+2 \mathrm{AH}_{3}$

Furthermore, the hydration of belite in the presence of aluminium hydroxide, which has already precipitated, leads to the formation of strätlingite $\left(\mathrm{C}_{2} \mathrm{ASH}_{8}\right)$ [6, 21, 27], according to Eq. 3:

$\mathrm{C}_{2} \mathrm{~S}+\mathrm{AH}_{3}+5 \mathrm{H} \rightarrow \mathrm{C}_{2} \mathrm{ASH}_{8}$

In the absence of aluminium hydroxide, calcium silicate hydrates $(\mathrm{C}-\mathrm{S}-\mathrm{H})$, and portlandite $(\mathrm{CH})$ precipitates $[6,8,21,28]$, according to Eq. 4 :

$\mathrm{C}_{2} \mathrm{~S}+n \mathrm{H} \rightarrow \mathrm{C}-\mathrm{S}-\mathrm{H}+m \mathrm{CH}$

Iron-containing siliceous hydrogarnet can be formed by the hydration of ferrite [6] in the presence of strätlingite, according to Eq. 5:

$\mathrm{C}_{2} \mathrm{ASH}_{8}+\mathrm{C}_{4} \mathrm{AF}+5 \mathrm{H} \rightarrow 2 \mathrm{C}_{3}(\mathrm{~A}, \mathrm{~F}) \mathrm{SH}_{4}+\mathrm{AH}_{3}$

After depletion of gypsum, ferrite hydration may also lead to an increase of monosulfate and to a decrease of gypsum according to Eq. 6.; the portlandite formed will participate in further reactions e.g. with aluminium hydroxide to form AFm phases, and iron hydroxide may be incorporated in iron-containing siliceous hydrogarnet.

$\mathrm{C}_{4} \mathrm{AF}+\mathrm{C}_{6} \mathrm{AS}_{3} \mathrm{H}_{32}+12 \mathrm{H}$
$\quad \rightarrow 3 \mathrm{C}_{4} \mathrm{~A} \overline{\mathrm{S}} \mathrm{H}_{12}+2 \mathrm{FH}_{3}+2 \mathrm{CH}$

While the influence of the source and amount of calcium sulfate on hydration has been widely studied in ye'elimite-rich calcium sulfoaluminate cements [10, 14-16, 29-31], only a limited number of studies have focused on belite-calcium sulfoaluminate cements, in which belite is the most abundant phase in the system. Chen \& Juenger [8] investigated clinkers with a differing content of belite and ye'elimite with calcium sulfate added to a varying degree, although belite was the predominant phase (60 wt.\%) in only one clinker sample. Even though, isothermal calorimetry was the only method used to investigate the hydration of these cements, the study revealed that the phase composition of clinker and the 
amount of calcium sulfate significantly affects the hydration kinetics; no data on phase composition and compressive strength is however available. Sulfaterich belite-calcium sulfoaluminate cements with different phase compositions were studied by Shen et al. [17], showing the significant effect of phase composition on compressive strength and hydrate assemblage. The influence of different anhydrite contents on compressive strength, hydration kinetics and phase assemblage in a belite-calcium sulfoaluminate cement was studied by Morin et al. [27]. No systematic influence of anhydrite quantity on compressive strength was found by the authors, while increasing the quantity of anhydrite retarded the dissolution of the $\alpha$-dicalcium silicate and ferrite phase present in the clinker. These results were confirmed by Zajac et al. [32], who observed that gypsum accelerated early hydration, while retarding late hydration. Furthermore the authors presented a micromechanical model to predict compressive strength.

Nevertheless, the data available regarding the impact of the quantities of calcium sulfate and belite/ye'elimite ratio of cement on the hydration kinetics and strength development of belite-calcium sulfoaluminate cements remains rather limited. In order to tackle the current research gaps, and improve understanding of the hydration processes of belitecalcium sulfoaluminate cements, a more systematic study is needed i.e. it is necessary to assess the influence of different amounts of gypsum and belite/ ye' elimite ratio of cement on the hydration of different belite-ye'elimite-ferrite systems, where hydration kinetics and the formation of hydration products are linked to the development of compressive strength and porosity.

The aim of this study is therefore to investigate the effect of the amount of calcium sulfate on the hydration of synthesized belite-calcium sulfoaluminate clinkers with two different phase compositions, using $M$-values of 1, 1.5 and 2 . The phase assemblages at 1, 7, 28 and 150 days of hydration are studied by $\mathrm{X}$-ray powder diffraction with Rietveld refinement and thermogravimetric analysis. Furthermore, hydration kinetics is investigated by isothermal calorimetry, and the compressive strength evolution is determined using mortar samples. In addition, a thermodynamic model is established applying the geochemical modelling code GEMS together with the cement-specific database CEMDATA18 in order to predict the evolution of the hydrate phases and to link compressive strength based on the calculated porosities.

\section{Materials and methods}

\subsection{Materials}

Six cements were prepared and investigated using either a belite-rich (CBCSA-B) or a ye'elimite-rich belite-calcium sulfoaluminate clinker (CBCSA-Y), and three different quantities of gypsum $(M=1,1.5$ and 2).

The targeted phase composition for the synthesized belite-rich clinker CBCSA-B was 65 wt. $\%$ belite $\left(\mathrm{C}_{2} \mathrm{~S}\right), 20 \mathrm{wt} . \%$ ye'elimite $\left(\mathrm{C}_{4} \mathrm{~A}_{3} \overline{\mathrm{S}}\right)$ and $10 \mathrm{wt} . \%$ ferrite $\left(\mathrm{C}_{4} \mathrm{AF}\right)$, compared to 50 wt.\% belite $\left(\mathrm{C}_{2} \mathrm{~S}\right)$, 35 wt.\% ye'elimite $\left(\mathrm{C}_{4} \mathrm{~A}_{3} \overline{\mathrm{S}}\right)$ and $10 \mathrm{wt} \%$ ferrite $\left(\mathrm{C}_{4} \mathrm{AF}\right)$ for the ye'elimite-rich CBCSA-Y. The investigated belite and calcium sulfoaluminate contents were chosen with respect to the compositions of BYF clinkers suggested by Morin et al. [33] (BCSA-B has maximum and BCSA-Y minimum belite content regarding their suggestion). Both clinkers were produced by firing appropriate mixtures of limestone, fly ash, bottom ash, calcined bauxite, titanogypsum and mill scale in a Protherm furnace PLF $160 / 9$ at $1250{ }^{\circ} \mathrm{C}$ at a heating rate of $10 \mathrm{~K} / \mathrm{min}$, with a holding time of $60 \mathrm{~min}$ at the final temperature followed by slow cooling in the closed furnace. The synthesis of cement clinkers is described in detail in Borštnar et al. [34]. Natural gypsum was used as the source of calcium sulfate.

$\mathrm{X}$-ray fluorescence analyses of the clinkers and gypsum were conducted according to EN 196-2 (Table 1), while phase compositions were derived from quantitative X-ray diffraction (Table 2). The actual phase compositions of the clinkers are close to the targeted ones. Besides ye'elimite, belite and ferrite, around 5 wt. $\%$ of minor phases (mayenite, periclase, gehlenite, $\gamma$-dicalcium silicate, perovskite, aphthitalite, arcanite) are present.

The synthesized clinkers were first ground below $0.125 \mathrm{~mm}$ in a vibratory disc mill (SIEBTECHNIK Labor Scheibenschwingmühle TS. 250) and afterwards using a ball mill (CAPCO Test Equipment Ball Mill Model 9VS). The Blaine specific surface areas of the cement clinkers, determined according to EN 
Table 1 Chemical analyses of the BCSA clinkers and gypsum, wt. \% (WD-XRF, fused beads)

\begin{tabular}{lccc}
\hline & CBCSA-B & CBCSA-Y & Gypsum \\
\hline $\mathrm{CaO}$ & 55.17 & 51.23 & 33.87 \\
$\mathrm{SiO}_{2}$ & 22.21 & 16.90 & 0.32 \\
$\mathrm{Al}_{2} \mathrm{O}_{3}$ & 12.15 & 19.55 & 0.05 \\
$\mathrm{Fe}_{2} \mathrm{O}_{3}$ & 3.62 & 3.66 & 0.04 \\
$\mathrm{MgO}$ & 1.53 & 1.28 & 0.39 \\
$\mathrm{~K}_{2} \mathrm{O}$ & 0.68 & 0.52 & $<0.04$ \\
$\mathrm{Na}_{2} \mathrm{O}$ & 0.29 & 0.23 & $<0.06$ \\
$\mathrm{TiO}_{2}$ & 0.674 & 1.068 & $<0.016$ \\
$\mathrm{P}_{2} \mathrm{O}_{5}$ & 0.092 & 0.091 & 0.006 \\
$\mathrm{Cr}_{2} \mathrm{O}_{3}$ & 0.083 & 0.078 & 0.002 \\
$\mathrm{MnO}$ & 0.060 & 0.047 & 0.003 \\
$\mathrm{SO}_{3}$ & 2.93 & 4.88 & 44.25 \\
L.O.I. $^{1}$ & 0.31 & 0.24 & 21.02 \\
Total & 99.77 & 99.76 & 99.95 \\
\hline
\end{tabular}

${ }^{1}$ Loss on ignition

196-6, were $4740 \mathrm{~cm}^{2} / \mathrm{g}$ (specific density $3.18 \mathrm{~g} / \mathrm{cm}^{3}$ ) for the CBCSA-B cement clinker and $4250 \mathrm{~cm}^{2} / \mathrm{g}$ (specific density $3.07 \mathrm{~g} / \mathrm{cm}^{3}$ ) for the CBCSA-Y. The gypsum was sieved to below $0.063 \mathrm{~mm}$ prior to use. The particle size distributions of the clinker and gypsum were determined using a laser particle analyzer (Malvern Mastersizer X). The powders were dispersed in isopropanol by ultrasound. The results are shown in Fig. 1. As expected from the Blaine values, the CBCSA-B clinker shows a slightly finer particle size distribution than clinker CBCSA-Y. The particle size distribution of the gypsum is broader than the distributions of the CBCSA clinkers.

The cement mixtures BCSA-B and BCSA-Y were prepared by blending the clinkers with different amounts of gypsum in order to achieve calcium sulfate to ye'elimite molar ratios ( $M$-values) of $1,1.5$ and 2 (see Table 3 ) in order to cover a wide range of $M$ values (rapid setting/hardening-expansive cements). Batches of $200 \mathrm{~g}$ were mixed in a Turbula powder blender mixer (WAB-group) for $2 \mathrm{~h}$ prior to use.

\subsection{Preparation of samples for hydration experiments}

The hydration experiments were carried out at $20{ }^{\circ} \mathrm{C}$, using a water to cement ratio of 0.50 . Cement pastes were mixed manually for 3 min using a spatula, filled into $15 \mathrm{ml}$ polyethylene vials and cured sealed at $20{ }^{\circ} \mathrm{C}$. Hydration was stopped by solvent exchange using isopropanol and diethyl ether [35] at 1, 7, 28 and 150 days. The crushed samples were submerged in isopropanol for $15 \mathrm{~min}$, filtered using a Büchner funnel, rinsed first with isopropanol and then twice with diethyl ether and finally dried for $8 \mathrm{~min}$ at $40{ }^{\circ} \mathrm{C}$ [36]. Afterwards, the dry pastes were ground by hand to a particle size of below $0.063 \mathrm{~mm}$ using an agate
Table 2 Phase

compositions of the BCSA clinkers and gypsum, determined by X-ray powder diffraction and Rietveld refinement, wt. \%

\begin{tabular}{lccc}
\hline & CBCSA-B & CBCSA-Y & Gypsum \\
\hline$\beta$-Dicalcium silicate (belite) & 60.6 & 50.9 & - \\
$\gamma$-Dicalcium silicate & 6.9 & 0.8 & - \\
Ye'elimite & 6.9 & 17.4 & - \\
orthorhombic & & & - \\
Ye'elimite & 9.3 & 14.9 & \\
cubic & & & - \\
Ferrite & 11.9 & 10.4 & - \\
Mayenite & 2.4 & 3.2 & - \\
Periclase & 1.2 & 1.0 & - \\
Gehlenite & 0.6 & - & - \\
Perovskite & - & 1.0 & - \\
Aphthitalite & 0.5 & 0.2 & - \\
Arcanite & 0.5 & 0.2 & 36.7 \\
Gypsum & - & - & 3.3 \\
Anhydrite & - & - & \\
\hline & & &
\end{tabular}




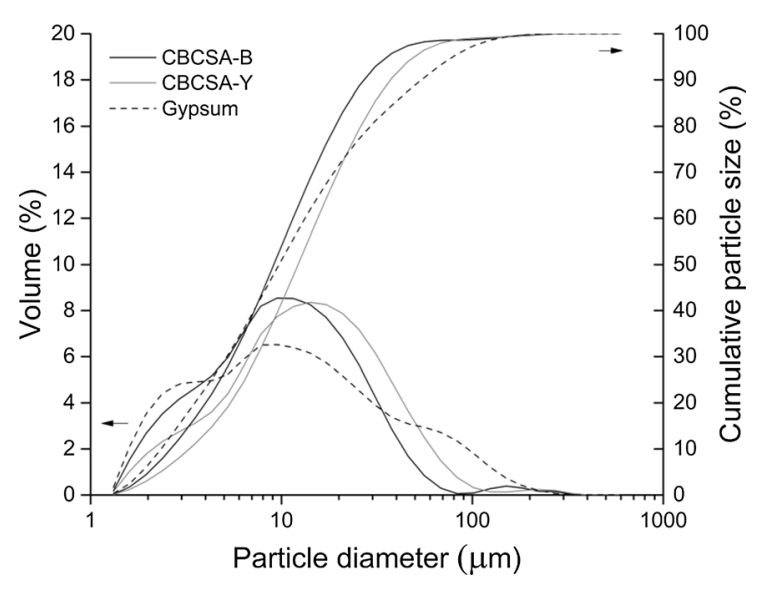

Fig. 1 Particle size distributions of cement clinkers CBCSA-B, CBCSA-Y, and gypsum

mortar and investigated by X-ray powder diffraction and thermogravimetric analyses.

\subsection{X-ray powder diffraction}

X-ray powder diffraction was performed using a PANalytical X'Pert Pro X-ray powder diffractometer equipped with a $\mathrm{CuK} \alpha \mathrm{X}$-ray tube, a Johannson $\mathrm{Ge}(111)$ incident beam monochromator and an X'Celerator detector. Samples were back-loaded into a circular sample holder (diameter $27 \mathrm{~mm}$ ) in order to reduce preferred orientation effects. Samples were measured at $45 \mathrm{kV}$ at a current of $40 \mathrm{~mA}$ in a $2 \theta$ range of $5-75^{\circ}$ with a step size of $0.017^{\circ} 2 \theta$, using a $1^{\circ}$ divergence slit and a $15 \mathrm{~mm}$ mask. The Rietveld refinements were performed using the PANalytical X'Pert High Score Plus V. 4.9 software and the crystal structures suggested by Snellings [37], with the exception of the structures of orthorhombic and cubic ye'elimite, which were taken from Cuesta et al. $[38,39]$. To quantify the total amorphous and poorly crystalline phases, the G-factor method [40-42] was used, with $\mathrm{CaF}_{2}$ (Sigma Aldrich) as an external standard. The results were normalized to $100 \mathrm{~g}$ of dry binder, taking into account the amount of bound water derived from the thermogravimetric analysis, which was determined from the weight loss at $550{ }^{\circ} \mathrm{C}$ [43].

\subsection{Thermogravimetric analyses}

Thermogravimetric (TGA) analyses of the hydrated samples were carried out using a Mettler Toledo TGA/ SDTA $851^{\mathrm{e}}$ in the temperature range 30 to $980{ }^{\circ} \mathrm{C}$ at a heating rate of $20 \mathrm{~K}$ per minute under a nitrogen atmosphere. About $60 \mathrm{mg}$ of the samples were placed in $150 \mu$ l alumina crucibles.

\subsection{Isothermal calorimetry}

Isothermal conduction calorimetry was performed to determine the hydration heat flow and cumulative heat of cement pastes using a TAM Air (TA instruments). $4 \mathrm{~g}$ of the prepared cement and $2 \mathrm{~g}$ of deionized water (at a water to cement ratio of 0.5 ) were mixed manually for 3 min using a spatula, filled into a glass ampoule, capped and then placed directly into the calorimeter. All measurements were carried out at $20{ }^{\circ} \mathrm{C}$ and recorded for $168 \mathrm{~h}$. The first $30 \mathrm{~min}$ of hydration could not be observed due to the external mixing procedure.

\subsection{Compressive strength}

For compressive strength measurements, mortars were prepared with quartz sand (CEN-Standard Sand EN 196-1-Normensand with grain sizes between 0.1 and $2 \mathrm{~mm}$ ), using a cement/sand ratio of $25 / 75$ by mass and a cement to water ratio of 0.50 . Mortars were mixed according to EN 196-1, cast in $25 \mathrm{~mm} \times 25$ $\mathrm{mm} \times 25 \mathrm{~mm}$ moulds, demoulded after $24 \mathrm{~h}$ and then cured at $20{ }^{\circ} \mathrm{C}$ and $95 \pm 2 \%$ relative humidity until
Table 3 Mix design (g/ $100 \mathrm{~g}$ cement) of the analysed cements

\begin{tabular}{|c|c|c|c|c|c|c|}
\hline & \multicolumn{3}{|c|}{ BCSA-B } & \multicolumn{3}{|c|}{ BCSA-Y } \\
\hline & $M=1$ & $M=1.5$ & $M=2$ & $M=1$ & $M=1.5$ & $M=2$ \\
\hline CBCSA-B & 95.5 & 93.3 & 91.3 & - & - & - \\
\hline CBCSA-Y & - & - & - & 91.3 & 87.5 & 83.9 \\
\hline Gypsum & 4.5 & 6.7 & 8.7 & 8.7 & 12.5 & 16.1 \\
\hline
\end{tabular}


testing. Compressive strength was determined at 1,7 , 28 and 150 days on six prism halves per measurement age using an LFM 50 testing machine (Walter + Bai) at a loading rate of $0.2 \mathrm{MPa} / \mathrm{s}$. ratio of 0.50 was applied, which corresponds to the value used in the experiments. For the $\mathrm{C}-\mathrm{S}-\mathrm{H}$, the CSHQ model from Kulik [49] was used.

Based on the thermodynamic calculations of the phase assemblage as a function over time it is possible

$P=\frac{V_{\text {unhydratedcement, } t=0}+V_{\text {hydrates, } t=0}+V_{\text {poresolution, } t=0}-V_{\text {hydrates }, t}-V_{\text {unhydratedcement, } t}}{V_{\text {unhydratedcement, } t=0}+V_{\text {hydrates, } t=0}+V_{\text {poresolution, } t=0}} \times 100$

\subsection{Thermodynamic modelling}

To predict the type and amount of hydrates formed during hydration of the anhydrous binders, thermodynamic modelling was carried out using the geochemical software GEMS $[44,45]$ coupled with the cementspecific CEMDATA 18 thermodynamic database [46].

As a first step the phase volumes during hydration of the BCSA clinkers blended with 0-30 wt.\% of gypsum were calculated. The phase compositions of the clinkers and the gypsum, as determined by X-ray powder diffraction, were used as inputs. A reaction degree of $100 \%$ was assumed for ye'elimite and mayenite, and of $50 \%$ for belite, ferrite and periclase, in agreement with the average long-term dissolution degrees reported in the literature e.g. by [14, 27, 32]. All the sulfate phases (anhydrite, gypsum, arcanite, aphthitalite) were allowed to fully react. Gehlenite, $\gamma$ belite and perovskite were considered as inert phases [15].

Furthermore, the phase changes with ongoing hydration were modelled. Here, the reaction degrees of the clinker phases depending on the hydration time obtained from X-ray powder diffraction were used and fitted with a sigmoidal non-linear equation (Eq. 7):

$\operatorname{DoR}=\frac{a-d}{1+\left(\frac{\mathrm{t}}{C}\right)^{b}}+d$

where DoR is the reaction degree, $t$ is the hydration time in days, $a$ is the minimum reaction degree (set to 0 ), $\mathrm{B}$ is the maximum steepness, $\mathrm{c}$ is the inflection point and $\mathrm{d}$ is the maximum reaction degree (set to 100) $[47,48]$.

All thermodynamic calculations were conducted at $20{ }^{\circ} \mathrm{C}$ under oxidizing conditions. A water to cement to calculate the porosities of the samples (Eq. 8):

where $P$ is the porosity in $\%, V$ is the volume in $\mathrm{cm}^{3}$, $t=0$ is the time at the beginning of hydration and $t$ is time [50].

\section{Results and discussion}

3.1 Thermodynamic modelling of the effect of gypsum on the hydrate assemblage

Figure 2a depicts the calculated long-term hydrate assemblages of the belite-rich BCSA-B clinker blended with different amounts of gypsum varying between 0 and 30 wt. \%. Without gypsum, or when the gypsum content is low $(<3 \mathrm{wt} \%)$, it is calculated that monosulfate, strätlingite, katoite $\left(\mathrm{C}_{3} \mathrm{AH}_{6}\right)$, siliceous hydrogarnet $\left(\mathrm{C}_{3}(\mathrm{~A}, \mathrm{~F}) \mathrm{S}_{0.84} \mathrm{H}_{4.32}\right), \mathrm{C}-\mathrm{S}-\mathrm{H}$ and hydrotalcite are calculated to be present. Above $4.5 \mathrm{wt} \%$ gypsum ettringite starts to form, and its amount increases along with an increase in gypsum, at the expense of monosulfate. The formation of the compared to monosulfate more water-rich ettringite results also in a lower amount of pore solution. $\mathrm{C}-\mathrm{S}-\mathrm{H}$ is more abundant than strätlingite. The latter phase becomes destabilized when higher contents of gypsum (above approximately $26 \mathrm{wt} . \%$ ) are used. Aluminium hydroxide is not calculated to be present when the gypsum content is above $2 \mathrm{wt} . \%$, as the aluminium hydroxide released by the hydration of ye'elimite is used for the formation of strätlingite, according to Eq. 3. The reaction of ferrite and belite is expected to result in some siliceous hydrogarnet containing both iron and aluminium. 
(a)

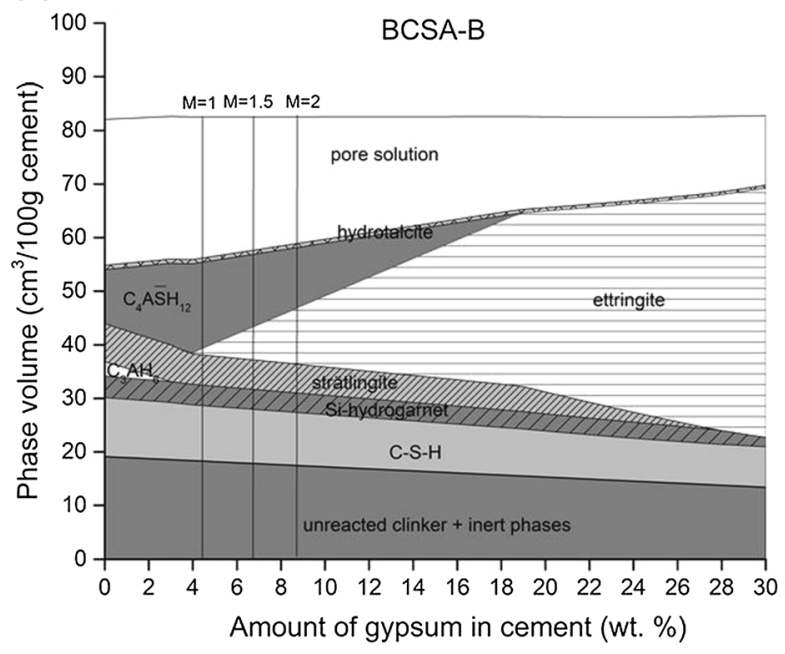

(b)

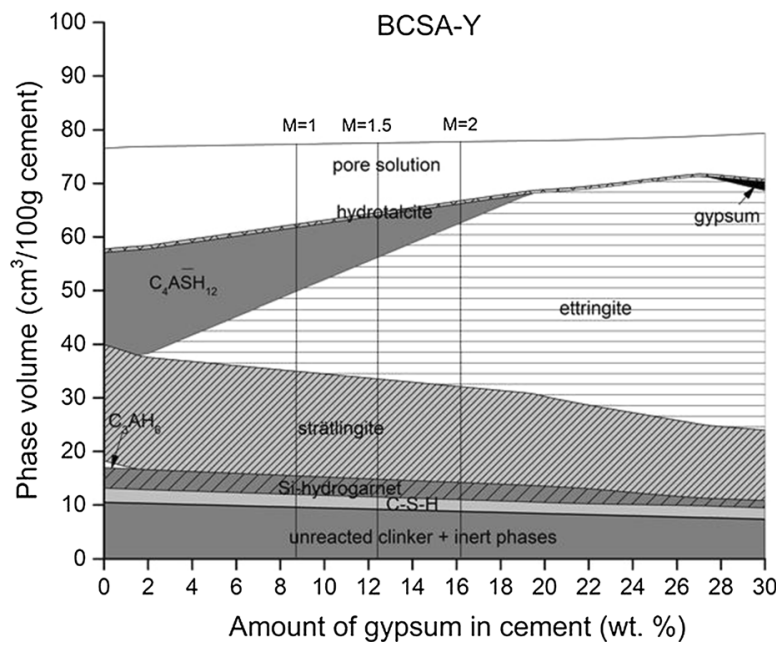

Fig. 2 Calculated hydrate assemblages in $\mathrm{cm} 3$ per $100 \mathrm{~g}$ unhydrated binder for a the belite-rich BCSA-B and $\mathbf{b}$ the ye'elimite-rich BCSA-Y cements, as a function of the amount of gypsum. The lines indicate the samples studied experimentally at $M=1,1.5$ and 2

Figure $2 \mathrm{~b}$ shows the calculated hydrate assemblages of the ye'elimite-rich BCSA-Y clinker blended with gypsum. As this clinker contains less belite and more ye'elimite than the BCSA-B, an equivalent $M$ ratio corresponds to a higher content of gypsum and thus to more ettringite and strätlingite. The formation of ettringite is calculated already at gypsum contents of 2 wt. $\%$ and above, while aluminium hydroxide is calculated to be absent over the entire range of gypsum additions. Due to the presence of less belite and more ye'elimite in this blend, less $\mathrm{C}-\mathrm{S}-\mathrm{H}$, but more strätlingite, is expected to form. Again, the formation of more ettringite in the presence of more gypsum lowers the amount of the pore solution, and this effect is more pronounced in the ye'elimite-rich BCSA-Y system compared to in the BCSA-B.

\subsection{Hydrate assemblage}

The XRD patterns of the investigated systems BCSA$\mathrm{B}$ and BCSA-Y with M-values of $1,1.5$ and 2 at 150 days of hydration are presented in Fig. 3. Patterns related to the samples at other ages are provided in Fig. S1 in the Electronic Supplementary Material (ESM). Normalized quantitative X-ray powder diffraction data of cements BCSA-B and BCSA-Y with calcium sulfate to ye'elimite molar ratios of 1.5 are shown in Fig. 4. Phase quantifications of the
Fig. 3 X-ray diffraction patterns of a BCSA-B and b BCSA-Y at $M=1,1.5$ and 2 at 150 days of hydration. $B=$ belite, $P=$ perovskite, $E=$ ettringite,

Ms = monosulfate, $S=$ strätlingite, $H=$ siliceous hydrogarnet (a)
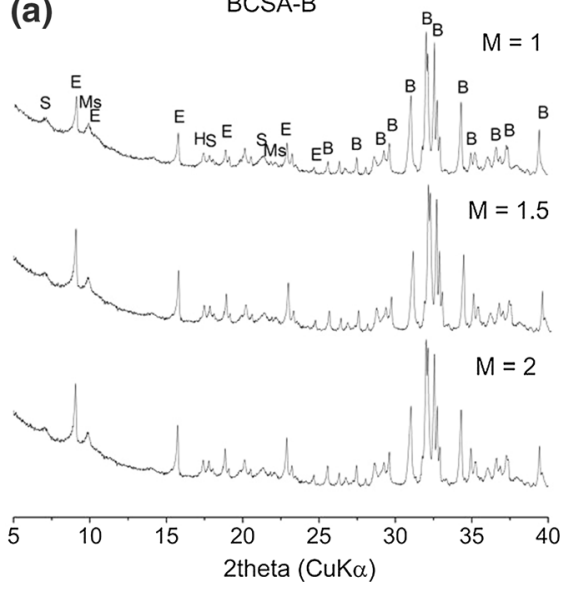

(b)
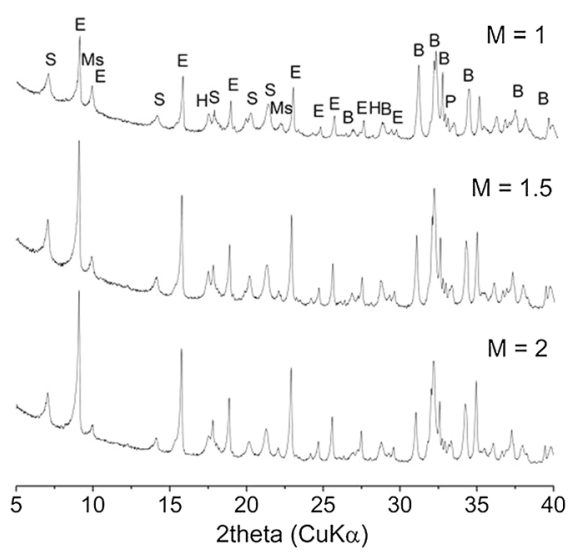
(a)

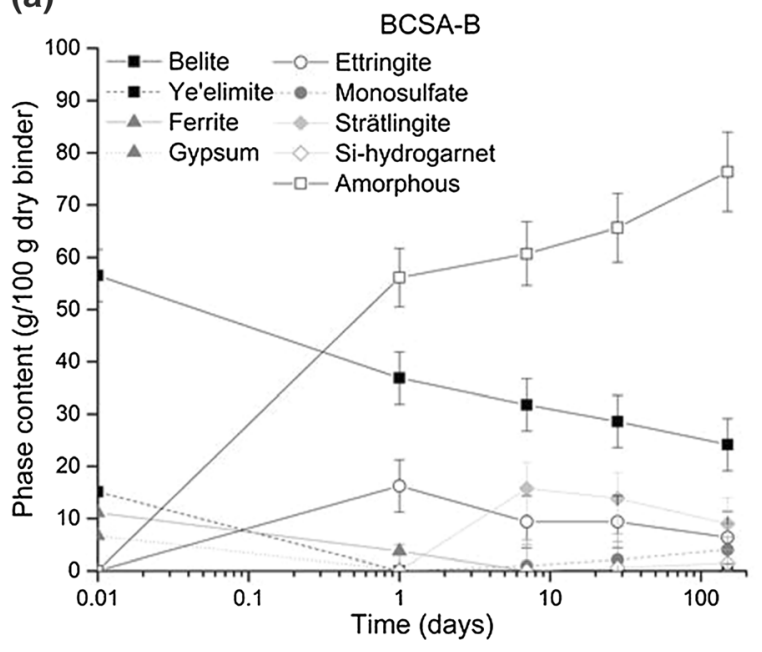

(b)

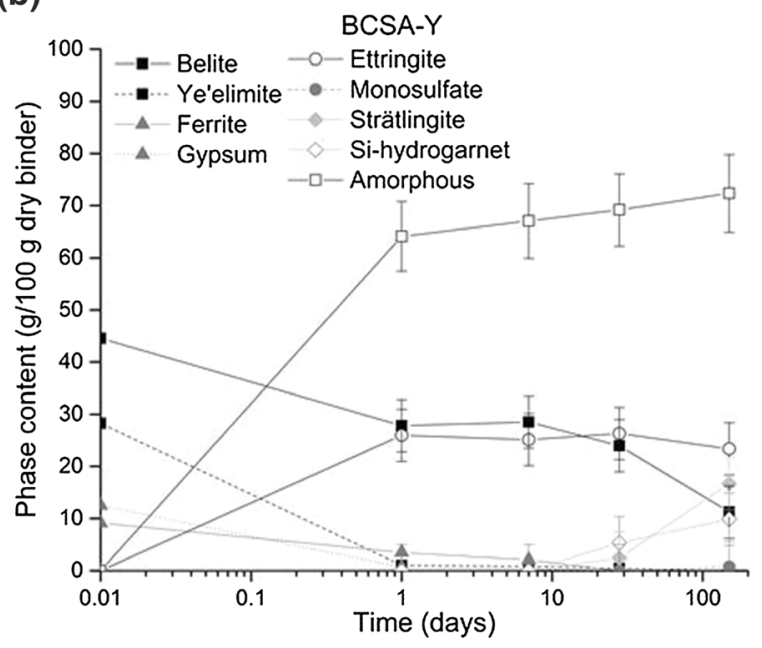

Fig. 4 X-ray powder diffraction quantification of the phase development in hydrating a BCSA-B and b BCSA-Y cement at $M=1.5$

(a)

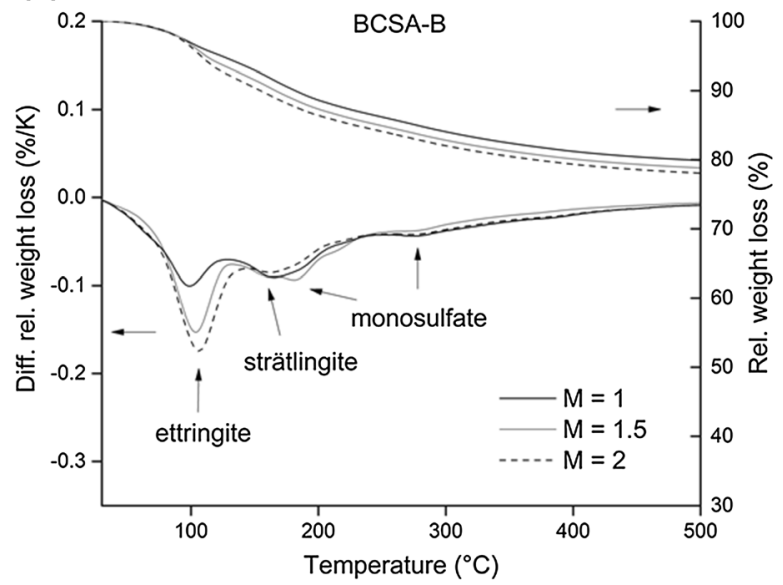

(b)

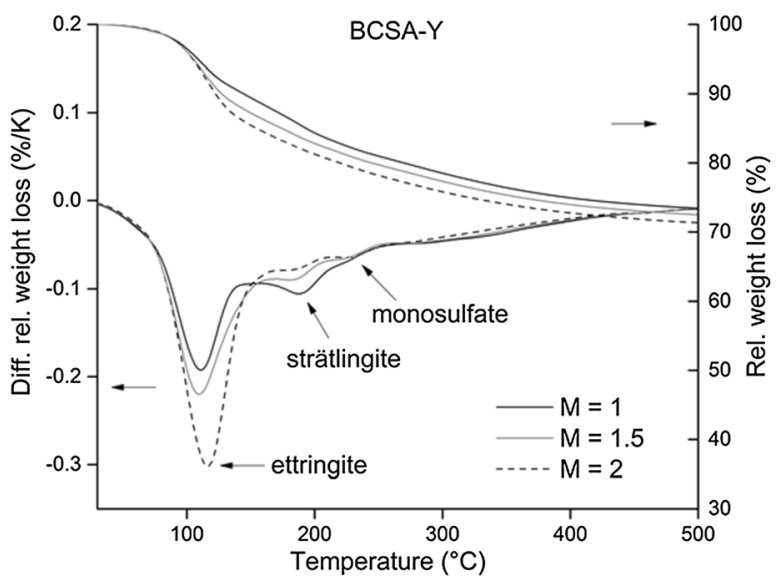

Fig. 5 Thermogravimetric analysis of cement pastes a BCSA-B and b BCSA-Y with the addition of different amounts of calcium sulfate at 150 days of hydration

samples with other molar ratios are provided in Fig. S2 in the ESM. Figure 5 plots the results of the thermogravimetric analyses of cements BCSA-B and BCSA$\mathrm{Y}$ with $\mathrm{M}$-values of $1,1.5$ and 2 at 150 days of hydration. TGA data of the samples at other curing times are available in Fig. S3 in the ESM.

The results of the BCSA-B cement mixtures (Figs. 3a and 4a) reveal that ye'elimite, as the early reacting phase, and gypsum have already dissolved within the first $24 \mathrm{~h}$ of hydration and are therefore not detected anymore at any of the calcium sulfate to ye'elimite molar ratios (see also Figs. S1-S3 in the
ESM). The hydration of ye'elimite in the presence of gypsum leads to the formation of ettringite, according to Eq. 1, until the gypsum is depleted. These results are consistent with the TGA analyses, where the main weight loss measured at $120{ }^{\circ} \mathrm{C}$ can be assigned to ettringite $[6,16,51]$ (see Fig. 5a and Fig. S3 in the ESM). After 7 days of hydration, the amount of ettringite decreases and the amount of monosulfate continues to increase with time due to the ongoing hydration of the ferrite phase (see Eq. 6), providing additional aluminium ions [51,52]. As expected, more ettringite is present at higher $M$-values, while the 
amount of monosulfate is lower, indicating that gypsum is controlling the ratio of precipitated ettringite to monosulfate, creating a shift from ettringite to monosulfate as the amount of gypsum decreases (Figs. 3a, 4a and 5a and Figs. S1-S3 in the ESM $[6,8,14,16,31])$. Belite dissolves as the hydration time increases, but is still present at 150 days of hydration, underlining the low reaction of belite in such aluminium-rich systems. The reaction degree of belite in the BCSA-B mixtures is rather independent of the calcium sulfate to ye'elimite molar ratio, reaching a value of approximately $60 \%$ at 150 days, similar to the data provided by Jeong et al.[14], Morin et al.[27] and Zajac et al. [32]. As sufficient water is available for hydration in these mixtures (see Fig. 2), the hydration of belite does not appear to be limited by a lack of water.

Ferrite is depleted after 7 days of hydration. At increasing M-values, however, more unreacted ferrite remained at 1 day, indicating that calcium sulfate delays the reaction of ferrite. This is consistent with the work of Morin et al. [27], which showed that the kinetics of the dissolution of ferrite is slower when higher amounts of calcium sulfate are added.. The authors speculated that an increasing lack of space due to precipitation of higher amounts of ettringite from previous ye'elimite hydration might be the reason for this delay.

Strätlingite is in BCSA-B identified from day 1 onwards at $\mathrm{M}=1$ and after 7 days of hydration at $M=1.5$ and 2 (see Figs. S1-S3 in the ESM), as a result of the hydration of belite with aluminium hydroxide $[21,27]$. Aluminium hydroxide is not detected by $\mathrm{X}$-ray powder diffraction as a result of its poor crystallinity, but it is visible in the TGA data (Fig. S3a), identifiable as a weight loss at around 250-280 ${ }^{\circ} \mathrm{C}[6,16,53]$. The amount of strätlingite slightly decreases at higher M-ratios (at $M=1.5$ and $M=2$ ), since the presence of more sulfate available for the formation of ettringite results in less aluminium available for the formation of strätlingite [14], confirming the findings of Jeong et al. [14] and Hargis et al. [54]. Moreover, after 28 days the reaction of ferrite, together with $\mathrm{Ca}$ from belite, $\mathrm{C}-\mathrm{S}-\mathrm{H}$, or strätlingite, leads to the formation of siliceous hydrogarnet containing iron $[6,33]$, according to Eq. 5. The presence of C-S-H is not confirmed by TGA due to its main hydration peak overlapping with that of ettringite [32].
In the BCSA-Y cement mixtures, gypsum and ye'elimite have not yet been consumed after 1 day of hydration (see Fig. 4b and Figs. S1, S2 in the ESM), while in the BCSA-B mixtures they are already fully dissolved at that time. In the BCSA-Y systems, the gypsum is fully dissolved after 7 days at $M=1$ and after 28 days at $M=1.5$, while it is still present after 150 days of hydration at $M=2$. At a high M-value more ettringite precipitates, which consumes more water and could slow down the hydration at later ages. This is far more evident at $M=2$, where etringite is the only hydration crystalline hydration product detected after 150 days. Ye'elimite dissolves more slowly than in the BCSA-B. A few percent are still present after 1 day of hydration, and small amounts persist until 150 days. As the M-value increases, the ye'elimite is consumed slightly faster.

Regarding the hydrate assemblage, the main difference between cements BCSA-Y and BCSA-B is the presence of more ettringite and less monosulfate in the BCSA-Y cement, which is in accordance with the thermodynamic modelling and TGA analysis and also observed by Chen \& Juenger [9]. However, the amount of ettringite significantly decreases with hydration time only at $M=1$, where monosulfate precipitated, while at $M=1.5$ and $M=2$ monosulfate is hardly identified, confirming that the amount of monosulfate decreases with an increasing amount of calcium sulfate addition. At $M=2$, ettringite is the only crystalline hydration product identified in large amounts, which, according to data from the literature causes a dense microstructure due to its high molar volume, thus hindering the dissolution of belite and the formation of other hydration products [8, 13, 14]. A slower dissolution of belite is therefore observed in the BCSA-Y cement as the addition of calcium sulfate is increased (see Fig. 4b and Fig. S2 in the ESM). At $M=2$ the amount of belite decreases only slightly between 1 and 150 days of hydration, confirming its hydration is delayed at such a high sulfate addition [27], as stated before, due to the high water consumption of ettringite, as the only crystalline hydration product identified, which slows down the hydration.

The amount of unreacted ferrite phase increases with an increasing M-value, which is consistent with the results of the BCSA-B cement. According to TGA some aluminium hydroxide is present, however not detected by XRD. At higher M-values (i.e. $M=2$ ) more aluminium hydroxide is observed in BCSA-Y 
compared to BCSA-B. This is the result of a higher amount of reacted ye'elimite in the presence of gypsum, more precipitated ettringite and therefore more aluminium ions present [16] and also due to a lower degree of hydration of belite to strätlingite, which consumes aluminium hydroxide.

The amount of strätlingite decreases with an increasing $\mathrm{M}$-value, again due to less aluminium available, as already observed in the BCSA-B cement. At $M=1$ strätlingite is identified after 7 days, at $M=1.5$ after 28 days, while at $M=2$ it could not clearly be identified after 150 days. Compared to the BCSA-B mixture, significantly less strätlingite is formed in the BCSA-Y mixture, which corresponds to the lower belite content of the ye'elimite-rich BCSA. Siliceous hydrogarnet is formed at $M=1$ and $M=1.5$ with the reaction of belite and ferrite after 28 days, when belite and ferrite have been consumed significantly. Its amount increases between 28 and 150 days. At $M=2$, siliceous hydrogarnet is not detected due to the low reaction degrees of belite and ferrite. In general, there is good agreement between the experimental data and the modelled phase assemblages. As predicted by thermodynamic modelling, the formation of ettringite, monosulfate, strätlingite and siliceous hydrogarnet as the main hydration products is also observed experimentally. Increasing the gypsum content led to the formation of more ettringite and less monosulfate, in agreement with previous observations [14].

(a)

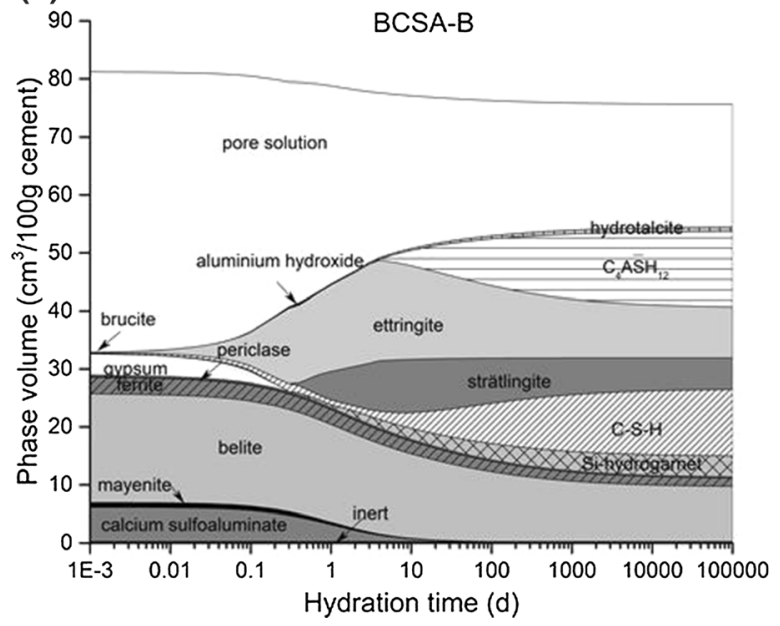

3.3 Thermodynamic modelling of phase development with time

Figure 6 shows changes in the phase contents of the BCSA-B and BCSA-Y cements with ongoing hydration when the $M$-value is 1.5 . Graphs for the cements with M-values of 1 and 2 can be found in the ESM (Fig. S4).

The modelled hydrate assemblages in both systems (BCSA-B, BCSA-Y) are similar; ettringite, aluminium hydroxide, monosulfate, strätlingite, $\mathrm{C}-\mathrm{S}-\mathrm{H}$, katoite and hydrotalcite are calculated. As hydration time increases, first the dissolution of ye'elimite and gypsum takes place, resulting in the precipitation of ettringite. Once the gypsum is consumed, the amount of ettringite decreases (especially in the BCSA-B), and monosulfate is formed. At higher $M$-values the gypsum is consumed later, and more ettringite but less monosulfate is formed. In general, higher amounts of ettringite and lower amounts of monosulfate are formed in the BCSA-Y compared to the BCSA-B. In the ye'elimite-rich BCSA-Y cement no monosulfate is predicted when $M=2$, as sufficient calcium sulfate is provided to make ettringite from the aluminium ions provided by ye'elimite and ferrite, which are not used to make strätlingite. Along with ettringite and monosulfate aluminium hydroxide is also formed, which is however consumed by the reaction with belite to form strätlingite. It is present only in small amounts in BCSA-B, while in BCSA-Y significantly higher

\section{(b)}

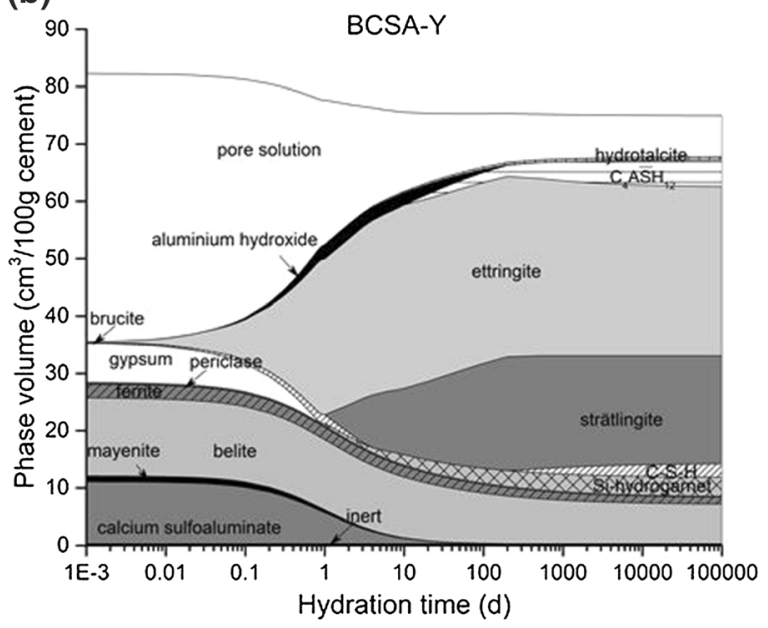

Fig. 6 Thermodynamic modelling of the phase assemblages depending on hydration time at $M=1.5$ for a the BCSA-B cement and b the BCSA-Y cement 
amounts of aluminium hydroxide precipitate. A small amount of siliceous hydrogarnet containing iron yields from the hydration of the belite and ferrite phases. The amount of $\mathrm{C}-\mathrm{S}-\mathrm{H}$ increases over time, while at the same time more belite also reacts. As expected, more strätlingite and $\mathrm{C}-\mathrm{S}-\mathrm{H}$ are formed in the belite-rich BCSA-B than in the ye'elimite-rich BCSA-Y. Traces of hydrotalcite are also calculated in all mixtures.

In general, there is good agreement between the experimental data and the modelled phase assemblages. As also observed by the experimental data, the calculations predict the formation of ettringite, aluminium hydroxide, monosulfate, strätlingite and siliceous hydrogarnet as the main hydration products. The observed increase and then later decrease in the quantities of ettringite, experimentally observed especially in the BCSA-B systems, is well represented in the calculations. $\mathrm{C}-\mathrm{S}-\mathrm{H}$, which is calculated to be present in trace amounts in BCSA-Y and in higher amounts in BCSA-B, could not be identified experimentally by XRD due to its poor crystallinity and due to overlapping peaks in TGA. Siliceous hydrogarnet seems to be over-estimated, which could be attributed to its slow formation at room temperature [2]. Hydrotalcite could not be identified in the experiments due to its low quantities and/ or crystallinity. Strätlingite, when it is present in only low amounts such as in the ye'elimite-rich BCSA-Y at $M=2$, is hard to identify due to the same reasons.

\subsection{Isothermal calorimetry}

The heat flow and cumulative heat data obtained by isothermal calorimetry are shown in Fig. 7. The initial peak, which is attributed to the wetting of the system, fast dissolution of clinker phases and early hydration reactions $[8,12,16-18,20]$ cannot be assessed due to the external mixing method and is thus not displayed and discussed.

All mixtures show a short induction period after the initial peak, which lasts for about 2 hours. Namely, this period is attributed to the slow dissolution of clinker phases and the slow formation of ettringite $[12,16,17]$.

Following this, the main hydration peak, which is attributed to the dissolution of ye'elimite and gypsum and the precipitation of ettringite together with aluminium hydroxide $[8,9,12,18,20]$, occurs after approximately 3.2 hours in both cement mixtures
BCSA-B and BCSA-Y [14], regardless of the amount of gypsum added.

A further, third heat maximum occurs, which is related to ongoing hydration after depletion of sulfate and the precipitation of monosulfate and/or the secondary formation of ettringite $[9,12,15,16]$. Its intensity increases with decreasing amounts of added gypsum, and its maximum is shifted to an earlier time. This indicates that, as more calcium sulfate is added, more ettringite precipitates according to Eq. 1, thus leaving less ye'elimite for the reaction according to Eq. $2[8,14,55]$. In the BCSA-B cement the third maximum occurs after $4,5.5$ and 6.5 hours at $M=1$, $M=1.5$ and $M=2$, respectively. In the BCSA-Y cement this peak appears later, after $6,8.5$ and $10 \mathrm{~h}$ at $M=1, M=1.5$, and $M=2$, respectively, which is due to the higher ye' elimite content in the BCSA-Y clinker compared to in the BCSA-B and therefore, as X-ray powder diffraction results showed, more ettringite and less monosulfate are formed.

Furthermore, another visible peak occurs in the BCSA-B cement mixtures, which is also shifted to an earlier time with a decreasing amount of added gypsum and occurs at 24 and 32 for $M=1$, and $M=$ 1.5. This peak appears at $M=2$ very late, only after 50 hours. This could be explained by the reaction of belite to yield strätlingite, while increasing gypsum delays the formation of strätlingite [14, 54], as confirmed by $\mathrm{X}$-ray powder diffraction (see Fig. 3 and Fig. S1 in the ESM). In the BCSA-Y system this additional peak probably related to belite hydration is hardly visible due to the lower quantities and the slower reaction of belite compared to the BCSA-B system.

The BCSA-Y cement mixtures show higher initial cumulative heat and also higher values after 7 days of hydration compared to the BCSA-B cement mixtures, indicating that the hydration of ye'elimite creates more heat than the hydration of belite (see Fig. 7c, d). In both BCSA-B and BCSA-Y the cumulative heat at all three M-ratios is rather similar.

\subsection{Compressive strength}

Results showing the compressive strength of the cement mixtures BCSA-B and BCSA-Y with differing amounts of gypsum are shown in Fig. 8.

All cements show rapid strength development at early ages due to the fast hydration of ye'elimite with gypsum and, consequently, the precipitation of a high 

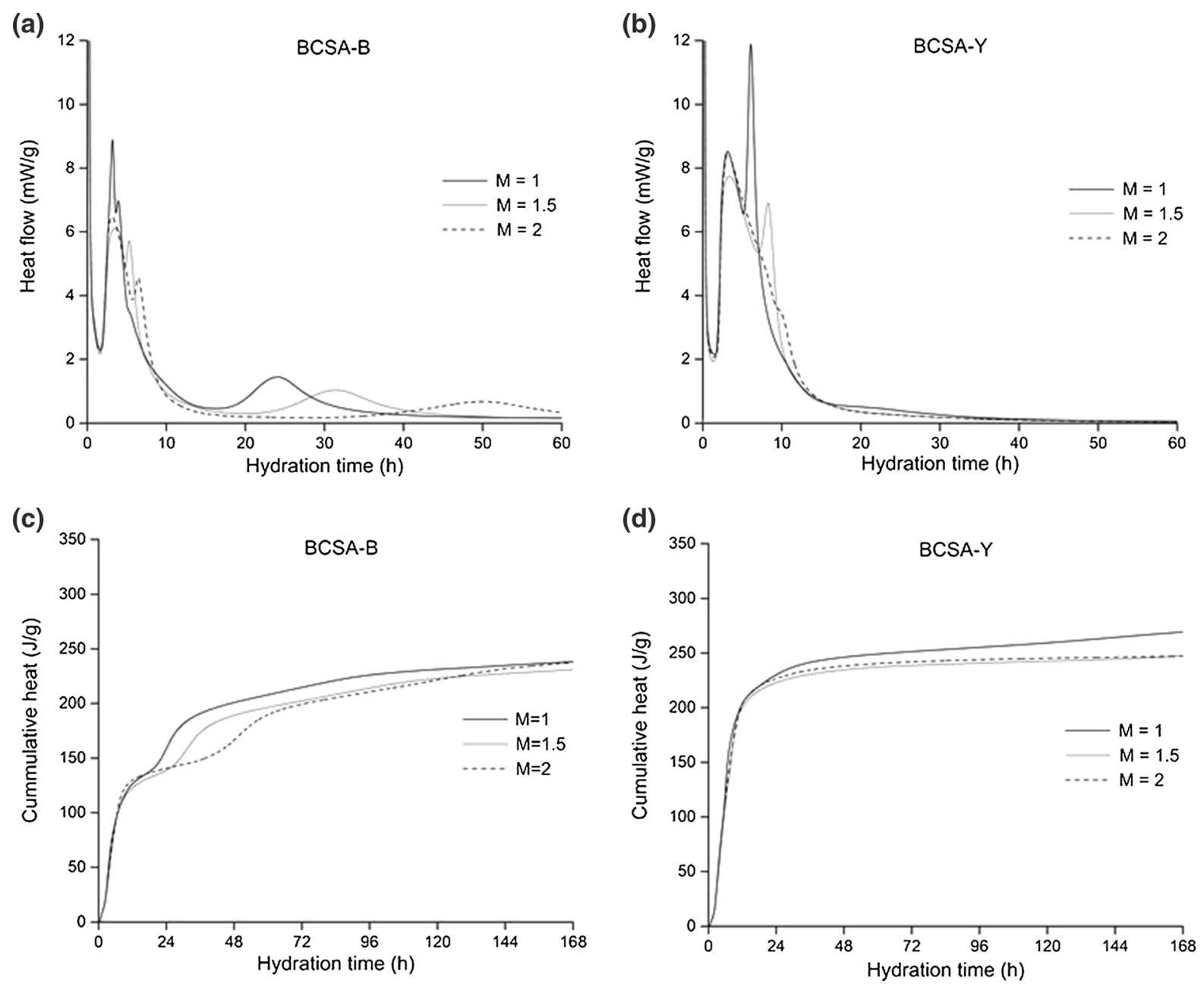

Fig. 7 Hydration heat flow of the a BCSA-B and b BCSA-Y cements and development of the cumulative heat of hydration in the c BCSA-B and d BCSA-Y cements blended with different amounts of gypsum

amount of ettringite $[2,14]$. This is in accordance with the results of X-ray diffraction and thermogravimetry, which reveal that gypsum has already been consumed within the first $24 \mathrm{~h}$ of hydration in the BCSA-B cements, while in the BCSA-Y a small amount remains unreacted.

All cement mixtures BCSA-B show a gradual increase in compressive strength up to 150 days, with very fast compressive strength development between 1 and 7 days (Fig. 8a). Beyond 7 days of hydration, the compressive strength increases slowly. At late ages (150 days) compressive strength is lowest when $M=2 \quad(24.9 \mathrm{MPa})$, followed by when $M=1$ (27.5 MPa), with the highest compressive strength developed when $M=1.5$ (30.3 MPa).
The compressive strength evolution of the BCSA-Y cement mixtures (Fig. 8b) shows a similar trend as to the BCSA-B cement mixtures, however at $M=1$ and $M=1.5$ only a slight strength gain between 1 and 7 days is observed in BCSA-B. After 7 days of hydration, the compressive strengths increase with an increasing amount of gypsum, as was also observed by Beltagui et al. [31], reaching final values of 39.6 MPa, 45.7 MPa, and 48.3 MPa at 150 days for $M=1, M=1.5$ and $M=2$, respectively. This effect is due to a higher amount of precipitated ettringite with increasing $M$-values, as confirmed by X-ray powder diffraction (see Fig. 3). Moreover, the compressive strength of the sample with $M=1$ is much lower with respect to the other two samples with $M$-values of 1.5 
(a)

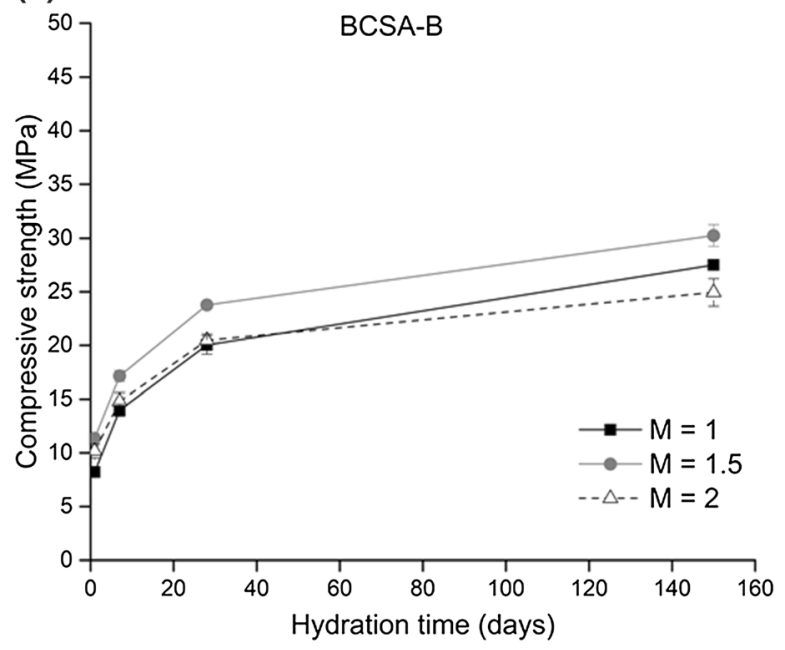

(b)

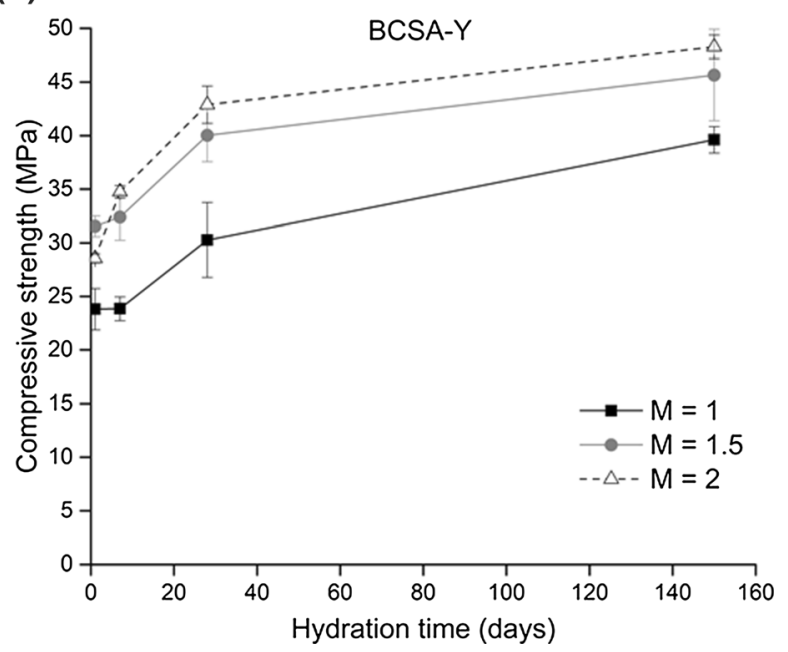

Fig. 8 Compressive strength development of the a BCSA-B and b BCSA-Y cements with differing amounts of gypsum

and 2, most likely due to much less ettringite formed at a low $M$-value.

The results show that the BCSA-Y cement mixtures have significantly higher compressive strengths than the BCSA-B cements at all hydration times, especially at an early age. This is due to the higher ye'elimite content and a higher amount of precipitated ettringite, as determined by X-ray powder diffraction and thermogravimetric analysis (Fig. 3), which has also been reported elsewhere $[2,8]$. These results are in accordance with isothermal calorimetry, where it can be seen that the cumulative heat flow is higher in BCSA-Y than in BCSA-B, especially at early ages.

Figure 9a plots the compressive strength versus bound water, as determined by thermogravimetric analyses, for both cement systems. Compressive strength increases as the bound water content increases, and a linear correlation is evidenced for all data points. The amount of bound water is related to the volume of hydration products, which itself is related to porosity and thus to compressive strength. (a)

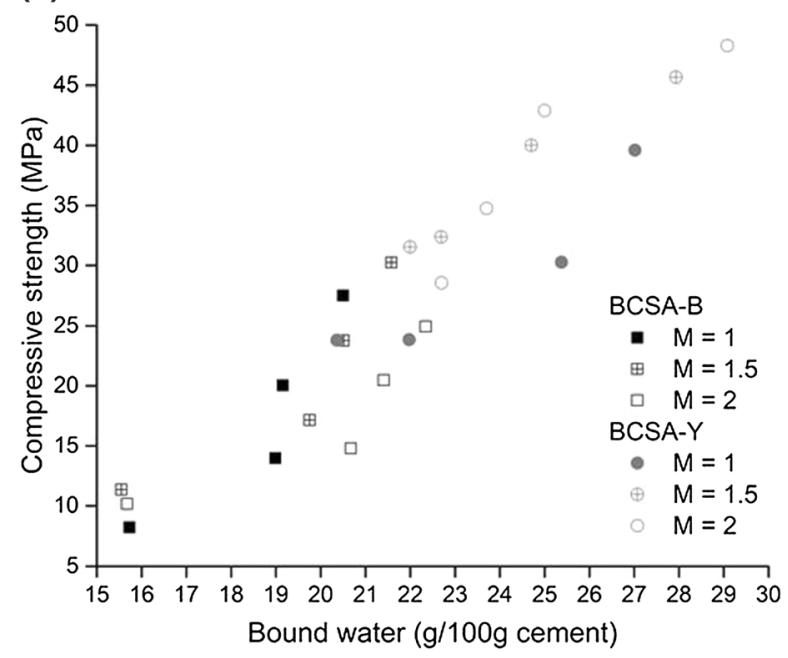

(b)

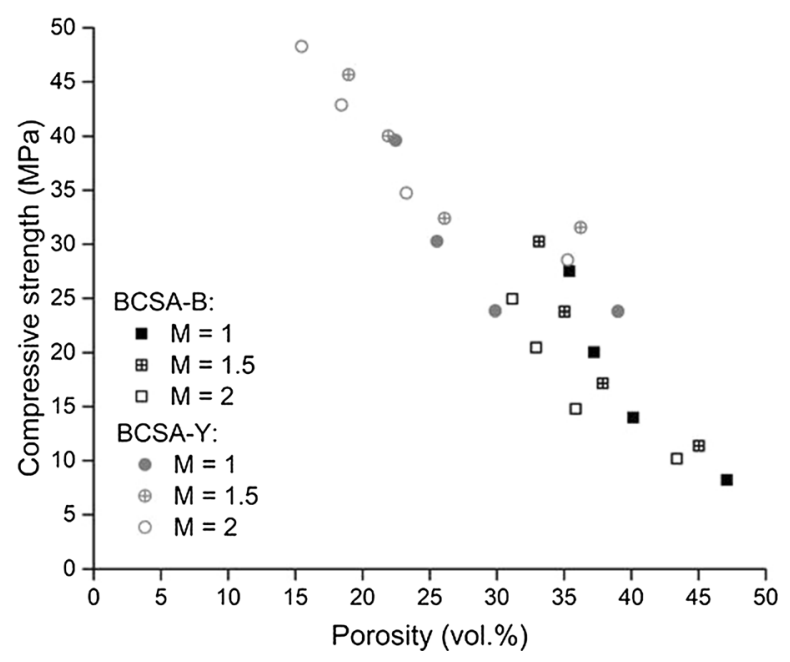

Fig. 9 a Bound water, as determined by TGA compared to measured compressive strength; b Calculated porosity compared to measured compressive strength 
In Fig. 9b compressive strength is plotted against the calculated porosities as derived from thermodynamic modelling. With decreasing porosity, the compressive strength increases. Again, all data points show a linear correlation between porosity and compressive strength. This indicates that, regardless of the phase compositions of the cements (i.e. different ye'elimite/belite and ye'elimite/gypsum ratios), compressive strength is mainly governed by the volume of hydrates formed and porosity.

\section{Conclusions}

In this study, the effect of various amounts of gypsum (calcium sulfate to ye'elimite molar ratios i.e. $M$ values of 1, 1.5 and 2) on the hydration mechanism of belite-rich and ye'elimite-rich belite-calcium sulfoaluminate cement clinkers was investigated by means of experimental methods and thermodynamic modelling.

In all systems investigated, the main hydration products at an early age are ettringite in addition to amorphous aluminium hydroxide, which precipitated due to the rapid hydration of ye'elimite in the presence of gypsum. After consumption of gypsum monosulfate forms, while the amount of ettringite decreases due to the supply of additional aluminium ions from dissolution of the ferrite phase. At later hydration times belite dissolves significantly, and siliceous hydrogarnet, strätlingite and $\mathrm{C}-\mathrm{S}-\mathrm{H}$ are formed.

The addition of gypsum plays an important role in the kinetics and phase assemblage formed during hydration. The cements react earlier and release more heat during the hydration when less gypsum is added (lower $M$-values). The amount of gypsum controls the quantities of ettringite and monosulfate precipitated, with an increasing amount of ettringite and a decreasing amount of monosulfate at higher $M$-ratios. With increasing amounts of the water-rich ettringite formed at increasing $M$-ratios, the water demand needed for full hydration increases and thus late hydration will slow down if the water/cement ratio applied is too low. Increasing the addition of gypsum decreases the dissolution kinetics of belite and ferrite. More strätlingite is formed at lower $M$-ratios due to less ettringite formed and therefore more aluminium is available for the formation of strätlingite. In the ye'elimite-rich clinker increasing the amount of gypsum increases compressive strength, as higher quantities of the space-filling ettringite are formed. In the belite-rich systems the differences were not as significant.

A higher amount of belite, and correspondingly less ye'elimite in the clinker, leads to higher amounts of $\mathrm{C}-$ $\mathrm{S}-\mathrm{H}$ at the expense of strätlingite. The cements with a higher belite content yielded significantly lower compressive strengths than the cements with lower belite contents as (i) the hydration degree of belite is significantly lower than the one of ye'elimite and (ii) ettringite is more space-filling than strätlingite and C$\mathrm{S}-\mathrm{H}$ [27].

The established thermodynamic hydration model shows good agreement compared to the experimental data and is able to predict the hydration of beliteye'elimite-ferrite cements. Compressive strength is directly correlated with bound water, as determined by thermogravimetric analysis, and inversely correlated to calculated porosity derived from thermodynamic modelling.

Funding The research is performed within the Young researcher programme and is financially supported by the Slovenian Research Agency, contract number 1000-18-1502.

\section{Declarations}

Conflict of interest The authors declare that they have no conflict of interest.

Open Access This article is licensed under a Creative Commons Attribution 4.0 International License, which permits use, sharing, adaptation, distribution and reproduction in any medium or format, as long as you give appropriate credit to the original author(s) and the source, provide a link to the Creative Commons licence, and indicate if changes were made. The images or other third party material in this article are included in the article's Creative Commons licence, unless indicated otherwise in a credit line to the material. If material is not included in the article's Creative Commons licence and your intended use is not permitted by statutory regulation or exceeds the permitted use, you will need to obtain permission directly from the copyright holder. To view a copy of this licence, visit http://creativecommons.org/licenses/by/4.0/.

\section{References}

1. Gartner E (2004) Industrially interesting approaches to "low-CO2" cements. Cem Concr Res 34:1489-1498. https://doi.org/10.1016/j.cemconres.2004.01.021

2. Lothenbach B, Albert B, Vincent M, Ellis G (2015) Hydration of Belite-Ye'elimite-Ferrite cements: 
thermodynamic modeling. In: 14th International conference on the chemistry of cement, Beijing, China, p. 12

3. Cuberos AJM, De la Torre ÁG, Álvarez-Pinazo G, MartínSedeño MC, Schollbach K, Pöllmann H, Aranda MAG (2010) Active iron-rich belite sulfoaluminate cements: clinkering and hydration. Environ Sci Technol 44:6855-6862. https://doi.org/10.1021/es101785n

4. Gartner E, Sui T (2018) Alternative cement clinkers. Cem Concr Res 114:27-39. https://doi.org/10.1016/j.cemconres. 2017.02.002

5. Quillin K (2001) Performance of belite-sulfoaluminate cements. Cem Concr Res 31:1341-1349. https://doi.org/10. 1016/S0008-8846(01)00543-9

6. Álvarez-Pinazo G, Santacruz I, Aranda MAG, De la Torre ÁG (2016) Hydration of belite-ye'elimite-ferrite cements with different calcium sulfate sources. Adv Cem Res 28:529-543. https://doi.org/10.1680/jadcr.16.00030

7. Juenger MCG, Winnefeld F, Provis JL, Ideker JH (2011) Advances in alternative cementitious binders. Cem Concr Res 41:1232-1243. https://doi.org/10.1016/j.cemconres. 2010.11.012

8. Chen IA, Juenger MCG (2011) Synthesis and hydration of calcium sulfoaluminate-belite cements with varied phase compositions. J Mater Sci 46:2568-2577. https://doi.org/10. 1007/s10853-010-5109-9

9. Chen IA, Juenger MCG (2012) Incorporation of coal combustion residuals into calcium sulfoaluminate-belite cement clinkers. Cem Concr Compos 34:893-902. https://doi.org/ 10.1016/j.cemconcomp.2012.04.006

10. García-Maté M, De la Torre AG, León-Reina L, Losilla ER, Aranda MAG, Santacruz I (2015) Effect of calcium sulfate source on the hydration of calcium sulfoaluminate eco-cement. Cem Concr Compos 55:53-61. https://doi.org/10. 1016/j.cemconcomp.2014.08.003

11. Jansen D, Spies A, Neubauer J, Ectors D, Goetz-Neunhoeffer F (2017) Studies on the early hydration of two modifications of ye'elimite with gypsum. Cem Concr Res 91:106-116. https://doi.org/10.1016/j.cemconres.2016.11. 009

12. Rungchet A, Poon CS, Chindaprasirt P, Pimraksa K (2017) Synthesis of low-temperature calcium sulfoaluminate-belite cements from industrial wastes and their hydration: comparative studies between lignite fly ash and bottom ash. Cem Concr Compos 83:10-19. https://doi.org/10.1016/j. cemconcomp.2017.06.013

13. Glasser FP, Zhang L (2001) High-performance cement matrices based on calcium sulfoaluminate-belite compositions. Cem Concr Res 31:1881-1886. https://doi.org/10. 1016/S0008-8846(01)00649-4

14. Jeong Y, Hargis CW, Chun S-C, Moon J (2018) The effect of water and gypsum content on strätlingite formation in calcium sulfoaluminate-belite cement pastes. Constr Build Mater 166:712-722. https://doi.org/10.1016/j.conbuildmat. 2018.01.153

15. Winnefeld F, Martin LHJ, Müller CJ, Lothenbach B (2017) Using gypsum to control hydration kinetics of CSA cements. Constr Build Mater 155:154-163. https://doi.org/ 10.1016/j.conbuildmat.2017.07.217

16. Winnefeld F, Barlag S (2010) Calorimetric and thermogravimetric study on the influence of calcium sulfate on the hydration of ye'elimite. J Therm Anal Calorim 101:949-957. https://doi.org/10.1007/s10973-009-0582-6

17. Shen Y, Li X, Chen X, Zhang W, Yang D (2018) Synthesis and calorimetric study of hydration behavior of sulfate-rich belite sulfoaluminate cements with different phase compositions. J Therm Anal Calorim 133:1281-1289. https://doi. org/10.1007/s10973-018-7251-6

18. Zhang L, Glasser FP (2002) Hydration of calcium sulfoaluminate cement at less than $24 \mathrm{~h}$. Adv Cem Res 14:15. https://doi.org/10.1680/adcr.2002.14.4.141

19. Telesca A, Marroccoli M, Pace ML, Tomasulo M, Valenti GL, Monteiro PJM (2014) A hydration study of various calcium sulfoaluminate cements. Cem Concr Compos 53:224-232. https://doi.org/10.1016/j.cemconcomp.2014. 07.002

20. Winnefeld F, Lothenbach B (2010) Hydration of calcium sulfoaluminate cements-experimental findings and thermodynamic modelling. Cem Concr Res 40:1239-1247. https://doi.org/10.1016/j.cemconres.2009.08.014

21. Gastaldi D, Paul G, Marchese L, Irico S, Boccaleri E, Mutke S, Buzzi L, Canonico F (2016) Hydration products in sulfoaluminate cements: Evaluation of amorphous phases by XRD/solid-state NMR. Cem Concr Res 90:162-173. https:// doi.org/10.1016/j.cemconres.2016.05.014

22. Zajac M, Skocek J, Bullerjahn F, Ben Haha M (2016) Effect of retarders on the early hydration of calcium-sulpho-aluminate (CSA) type cements. Cem Concr Res 84:62-75. https://doi.org/10.1016/j.cemconres.2016.02.014

23. Jeong Y, Hargis CW, Kang H, Chun S-C, Moon J (2019) The effect of elevated curing temperatures on high ye'elimite calcium sulfoaluminate cement mortars. Materials 12:1072. https://doi.org/10.3390/ma12071072

24. Zhang L, Su M, Wang Y (1999) Development of the use of sulfo- and ferroaluminate cements in China. Adv Cem Res 11:15-21. https://doi.org/10.1680/adcr.1999.11.1.15

25. Li GS, Walenta G, Gartner E (2007) Formation and hydration of low $\mathrm{CO} 2$ cements based on belite, calcium sulfoaluminate and calcium aluminoferrite. In: Proceedings of the 12th ICCC, Montreal, Canada, pp. 9-12

26. Zajac M, Skocek J, Bullerjahn F, Lothenbach B, Scrivener K, Ben Haha M (2019) Early hydration of ye'elimite: insights from thermodynamic modelling. Cem Concr Res 120:152-163. https://doi.org/10.1016/j.cemconres.2019.03. 024

27. Morin V, Termkhajornkit P, Huet B, Pham G (2017) Impact of quantity of anhydrite, water to binder ratio, fineness on kinetics and phase assemblage of belite-ye'elimite-ferrite cement. Cem Concr Res 99:8-17. https://doi.org/10.1016/j. cemconres.2017.04.014

28. Bullerjahn F, Schmitt D, Ben Haha M (2014) Effect of raw mix design and of clinkering process on the formation and mineralogical composition of (ternesite) belite calcium sulphoaluminate ferrite clinker. Cem Concr Res 59:87-95. https://doi.org/10.1016/j.cemconres.2014.02.004

29. Telesca A, Marroccoli M, Winnefeld F (2019) Synthesis and characterisation of calcium sulfoaluminate cements produced by different chemical gypsums. Adv Cem Res 31:113-123. https://doi.org/10.1680/jadcr.18.00122

30. Zhang J, Guan X, Wang X, Ma X, Li Z, Xu Z, Jin B (2020) Microstructure and properties of sulfoaluminate cementbased grouting materials: effect of calcium sulfate variety. 
Adv Mater Sci Eng 2020:1-8. https://doi.org/10.1155/2020/ 7564108

31. Beltagui H, Jen G, Whittaker M, Imbabi MS (2017) The influence of variable gypsum and water content on the strength and hydration of a belite-calcium sulphoaluminate cement. Adv Appl Ceram 116:199-206. https://doi.org/10. 1080/17436753.2017.1289722

32. Zajac M, Skocek J, Stabler C, Bullerjahn F, Ben Haha M (2019) Hydration and performance evolution of beliteye'elimite-ferrite cement. Adv Cem Res 31:124-137. https://doi.org/10.1680/jadcr.18.00110

33. Gartner E, Walenta G, Morin V, Termkhajornkit P, Baco I, Casabonne JM (2011) Hydration of a belite-calciumsulfoaluminate-ferrite cement: aetherTM

34. Borštnar M, Daneu N, Dolenec S (2020) Phase development and hydration kinetics of belite-calcium sulfoaluminate cements at different curing temperatures. Ceram Int 46:29421-29428. https://doi.org/10.1016/j.ceramint.2020. 05.029

35. Snellings R, Chwast J, Cizer Ö, De Belie N, Dhandapani Y, Durdzinski P, Elsen J, Haufe J, Hooton D, Patapy C, Santhanam M, Scrivener K, Snoeck D, Steger L, Tongbo S, Vollpracht A, Winnefeld F, Lothenbach B (2018) Report of TC 238-SCM: hydration stoppage methods for phase assemblage studies of blended cements-results of a round robin test. Mater Struct 51:111. https://doi.org/10.1617/ s11527-018-1237-5

36. Snellings R, Chwast J, Cizer Ö, Belie N, Dhandapani Y, Durdziński P, Elsen J, Haufe J, Hooton D, Patapy C, Santhanam M, Scrivener K, Snoeck D, Steger L, Tongbo S, Vollpracht A, Winnefeld F, Lothenbach B (2018) RILEM TC-238 SCM recommendation on hydration stoppage by solvent exchange for the study of hydrate assemblages. Mater Struct. https://doi.org/10.1617/s11527-018-1298-5

37. Snellings R (2016) X-ray powder diffraction applied to cement. In: A practical guide to microstructural analysis of cementitious materials, First, CRC Press, pp. 126-195. Doi: https://doi.org/10.1201/b19074-4

38. Cuesta A, De la Torre ÁG, Losilla ER, Santacruz I, Aranda MAG (2014) Pseudocubic crystal structure and phase transition in doped ye'elimite. Cryst Growth Des 14:5158-5163. https://doi.org/10.1021/cg501290q

39. Cuesta A, De la Torre AG, Losilla ER, Peterson VK, Rejmak P, Ayuela A, Frontera C, Aranda MAG (2013) Structure, atomistic simulations, and phase transition of stoichiometric yeelimite. Chem Mater 25:1680-1687. https://doi.org/10.1021/cm400129z

40. Jansen D, Goetz-Neunhoeffer F, Stabler C, Neubauer J (2011) A remastered external standard method applied to the quantification of early OPC hydration. Cem Concr Res 41:602-608. https://doi.org/10.1016/j.cemconres.2011.03. 004

41. Jansen D, Stabler Ch, Goetz-Neunhoeffer F, Dittrich S, Neubauer J (2011) Does ordinary portland cement contain amorphous phase? A quantitative study using an external standard method. Powder Diffr 26:31-38. https://doi.org/ 10.1154/1.3549186

42. O'Connor BH, Raven MD (1988) Application of the rietveld refinement procedure in assaying powdered mixtures. Powder Diffr 3:2-6. https://doi.org/10.1017/ S0885715600013026
43. Lothenbach B, Durdzinski P, De Weerdt K (2016) Thermogravimetric analysis. In: A practical guide to microstructural analysis of cementitious materials, First, CRC Press, https://www.taylorfrancis.com/chapters/thermogravimetric-analysis-barbara-lothenbachpawe\%C5\%82-durdzi\%C5\%84ski-klaartje-de-weerdt/e/ https://doi.org/10.1201/b19074-5 (accessed February 19, 2021)

44. Wagner T, Kulik DA, Hingerl FF, Dmytrieva SV (2012) GEM-Selektor geochemical modeling package: TSolMod library and data interface for multicomponent phase models. Contrib Can Mineral 50:1173-1195. https://doi.org/10. 3749/canmin.50.5.1173

45. Kulik DA, Wagner T, Dmytrieva SV, Kosakowski G, Hingerl FF, Chudnenko KV, Berner U (2013) GEMSelektor geochemical modeling package: revised algorithm and GEMS3K numerical kernel for coupled simulation codes. Comput Geosci 17:1-24. https://doi.org/10.1007/ s10596-012-9310-6

46. Lothenbach B, Kulik DA, Matschei T, Balonis M, Baquerizo L, Dilnesa B, Miron GD, Myers RJ (2019) Cemdata18: a chemical thermodynamic database for hydrated Portland cements and alkali-activated materials. Cem Concr Res 115:472-506. https://doi.org/10.1016/j.cemconres.2018.04. 018

47. Kulik DA, Winnefeld F, Kulik A, Miron GD, Lothenbach B (2021) CemGEMS - an easy-to-use web application for thermodynamic modeling of cementitious materials. RILEM Tech Lett 6:36-52. https://doi.org/10.21809/ rilemtechlett.2021.140

48. Chitvoranund N, Winnefeld F, Hargis CW, Sinthupinyo S, Lothenbach B (2017) Synthesis and hydration of alite-calcium sulfoaluminate cement. Adv Cem Res 29:101-111. https://doi.org/10.1680/jadcr.16.00071

49. Kulik DA (2011) Improving the structural consistency of CS-H solid solution thermodynamic models. Cem Concr Res 41:477-495. https://doi.org/10.1016/j.cemconres.2011.01. 012

50. Lothenbach B, Matschei T, Möschner G, Glasser FP (2008) Thermodynamic modelling of the effect of temperature on the hydration and porosity of Portland cement. Cem Concr Res 38:1-18. https://doi.org/10.1016/j.cemconres.2007.08. 017

51. Meller N, Hall C, Jupe AC, Colston SL, Jacques SDM, Barnes P, Phipps J (2004) The paste hydration of brownmillerite with and without gypsum: a time resolved synchrotron diffraction study at $30,70,100$ and $150{ }^{\circ} \mathrm{C}$. J Mater Chem 14:428-435. https://doi.org/10.1039/B313215C

52. Möschner G, Lothenbach B, Winnefeld F, Ulrich A, Figi R, Kretzschmar R (2009) Solid solution between Al-ettringite and Fe-ettringite $(\mathrm{Ca} 6[\mathrm{Al}-\mathrm{xFex}(\mathrm{OH}) 6] 2(\mathrm{SO} 4) 3 \cdot 26 \mathrm{H} 2 \mathrm{O})$. Cem Concr Res 39:482-489. https://doi.org/10.1016/j. cemconres.2009.03.001

53. Scrivener K, Snellings R, Lothenbach B (2016) A practical guide to microstructural analysis of cementitious materials. CRC Press, Boca Raton

54. Hargis CW, Lothenbach B, Müller CJ, Winnefeld F (2019) Further insights into calcium sulfoaluminate cement expansion. Adv Cem Res 31:160-177. https://doi.org/10. 1680/jadcr.18.00124 
55. Jeong Y, Hargis C, Chun S, Moon J (2017) Effect of calcium carbonate fineness on calcium sulfoaluminate-belite Cement. Materials 10:900. https://doi.org/10.3390/ ma10080900
Publisher's Note Springer Nature remains neutral with regard to jurisdictional claims in published maps and institutional affiliations. 